\title{
'HOW DID A WHITE GIRL GET AIDS?' SHIFTING STUDENT PERCEPTIONS ON HIV-STIGMA AND DISCRIMINATION AT A HISTORICALLY WHITE SOUTH AFRICAN UNIVERSITY
}

\author{
A. Brown \\ Faculty of Education Sciences \\ North-West University \\ Potchefstroom, South Africa \\ e-mail: 25770098@nwu.ac.za
}

\section{ABSTRACT}

Classroom discussions with predominantly White, middle-class student teachers revealed that they still perceive HIV as a disease which Black, poor and promiscuous people bring on themselves. Unless such beliefs are problematized, they are likely to be perpetuated in their teaching of HIV and sex education in the Life Orientation classroom. To disrupt this thinking, I invited a professional White woman who has lived with HIV for the past 16 years to share her lived experiences. Students constructed drawings and narratives to reflect on their understanding of HIV before and after the guest lecture. These reflections served to disrupt student thinking about HIV. Thematic analysis indicated a shift in response from distancing, blame and rejection towards care, understanding, support and hope. This pedagogical strategy created an opportunity for trainee teachers to begin to think how they could contribute as teachers towards creating a more inclusive citizenry as a riposte to the history of division, discrimination and 'othering' in South Africa.

Keywords: discrimination, drawings, HIV and AIDS education, Life Orientation, 'Othering', teacher education

\section{INTRODUCTION AND CONTEXT OF THE STUDY}

South Africa has the highest HIV prevalence globally (5.51 million people infected) with a recorded 3.7 million orphans, the majority of whom are of school-going age (Statistics South Africa 2014). This reality locates the issue of HIV prevention and care squarely in and around the classroom. In the absence of a cure or vaccine for HIV, education has emerged as an important hope to counteract the uncertainty presented by this disease (Mitchell, De Lange, Moletsane, Stuart and Buthelezi 2005). Teachers are expected to equip all learners with accurate HIV knowledge (Department of Basic Education 2012) and skills to lessen their vulnerability. Although school-based prevention programmes have been shown to reduce prevalence of sexual risk behaviour (Matthews, Bloon, Flisher and Schaalma 2006), the reality shows a different picture. Teachers are thus seen as the key resources in the reduction of HIV prevalence 
among the youth (Wood and Rolleri 2014). Teachers, however have generally been educated only about the basics of HIV transmission, and/or stigma reduction and many remain uncomfortable and unwilling to address issues such as safe sex and sexual diversity (Holderness 2012). Teaching about HIV and AIDS and sexuality is not value free and is often seen by some South African teachers as controversial topics that should be left out of the curriculum (Helleve, Flisher, Onya, Mukoma and Klepp 2011). In addition, teaching is impeded by teachers' own sociocultural and religious beliefs (Pelzer and Promtusananon 2003; Holderness 2012; Themane and Taole 2013). There is an urgency for teacher critical self-awareness of how HIV impacts learners, their families, communities and broader society (HEAIDS 2010). This includes the complexity of diversity, race, class and gender and aspects of equality.

After nearly 40 years of documented HIV prevalence in South Africa, young people more than half that age hold onto misconceptions that were constructed in the early days of the pandemic. Despite the volumes of research reports on HIV education in South Africa, there is still considerable evidence that teachers are not approaching it from the nuanced and intersectional perspective needed to reduce the stigma and stereotyping around HIV vulnerability and support of those infected (Skinner and Mfecane 2004; Mathews, Boon, Flisher and Schaalma 2006; Simbayi, Kalichman, Strebel, Cloete et al. 2007; Helleve, Flisher, Onya, Kaaya et al. 2009; HEAIDS 2010; Wood 2013). This article explores how critical pedagogy (Freire 2000) could be applied to bring a balance between student teachers' abstract clinical knowledge of HIV education and knowledge of human diversity, social justice and democratic imperatives.

This article reports on the use of drawing and narratives as a critical pedagogical tool to shift student teachers' narrow, racialized and gendered perceptions of HIV towards a more nuanced and intersectional (Watkins-Hayes 2014) understanding of the pandemic. I conceived this study after realizing that students in the B Ed Life Orientation programme, who are predominantly middle-class and White, still hold onto various forms of conservative, religious and inaccurate social constructions of HIV. These negative stereotypes by White student teachers must surely influence their willingness and (in)competence to address issues embedded in the LO syllabus which relate inter alia to HIV, gender, sexuality education, diversity and responsible citizenship. The lack of an intersectional perspective on HIV and AIDS will perpetuate false notions of vulnerability and subsequently place their learners at risk of infection (Nduna and Mendes 2010). Failure to disrupt such thinking will also perpetuate divisions in society, rather than work towards unity and equality, basic pillars on which the school curriculum is based. I thus decided to use critical pedagogical strategies (Freire 2000) to raise 
the critical awareness of students around their attitudes and beliefs about HIV, gender, race and class.

\section{POSITIONING HIV EDUCATION FOR PRE-SERVICE TEACHERS}

HIV stigma and discrimination cannot be understood without interrogation of their intersection with constructs such as race, class, gender and socio-historical events and how these influence understanding of the disease and behaviour of the afflicted. Despite the advances in medical interventions for people living with HIV and AIDS (PLWHA), HIV stigma and discrimination continue to marginalise those infected and affected (Hamra, Ross, Karuri, Orr et al. 2005; Rao, Kekwaletswe, Hosek, Martinez et al. 2007; Francis 2008; Holderness 2012; Van Dyk, 2012). Parker, Aggleton, Attawell, Pulerwitz et al. $(2002,16)$ define HIV stigma as,

... the process of devaluation that involves the identification of 'undesirable difference', the creation of spoiled identities, process of distancing and of personal and societal denial. It is also a process by which people place themselves outside the epidemic, seeing themselves somehow protected and quite unlike those who are stigmatised.

Stigma and discrimination could be directed at either an individual or at societal/community level - in either case it involves the loss of status and 'othering' of the marginalized individual or group (Skinner and Mfecane 2004). Such marginalisation leads to those affected by HIV being seen as somehow responsible for their status, which in turn increases the tendency for discrimination on many levels. Those discriminated against develop a stained social identity which ultimately limits their ability to confidently address their needs (Brown, BeLue and Airhihenbuwa 2010). Swartz, Arogundade and Davis (2014) point out that privileged, mainly White South Africans have financial security, access to education and quality health services which influence their daily choices and outlook towards those who are less privileged. This has led to PLWHA being treated as 'those', a concept known as 'othering'.

The concept and practice of 'othering' can be defined as a personal, social, cultural and historical experience involving cultural and racial ambiguity, categorization and labelling, hierarchical power dimensions and limited access to resources (Borrero, Yeh, Cruz and Suda 2012, 1). Krumer-Nevo and Sidi (2012) explain that moral coding is fundamental within the process of 'othering' and it is conducted on the basis of behaviour set by a homogeneous group. I do not argue for a homogeneous human race, on the contrary I acknowledge and celebrate inherent differences amongst humanity. However, when these differences are instituted to make people feel like an 'out-group' then there is a need to pay attention to the intended and unintended meanings implied by difference. The out-group is perceived to be disadvantaged 
and 'bad', while the in-group is privileged and 'good' (Van Breda 2012; Vikenburg 2014). 'Othering' should not be construed as only a label but as an action that has disrespectful and harmful consequences (Kischner 2012). With reference to HIV-related stigma and discrimination in South Africa and a history which was built along the lines of race, class and gender, the disadvantages are not necessarily a mere imagination of the in-group but could be caught up in the realities of the historical, social, economic and political disparities of the inand out-group (Dunbar 2013). These are the components that strengthen the process of 'othering' and create a widening distance between the two groups. There is a critical need to change the lenses through which we look at the disadvantages of the out-group.

HIV stigma in South Africa cannot therefore be separated from the equally stigmatised constructs of poverty and race. Likewise, since sex is the main transmission route for HIV, the socio-economic, cultural and perceived moral meanings attached to it also have to be explored to make sense of the different layers of associated stigma. The constructed understanding of HIV is inextricably enmeshed with other stigmas of AIDS and sex, disease and death and behaviours that are generally perceived as illegal, forbidden or taboo, e.g., pre- and extramarital sex, sex workers, men having sex with men and drug abusers (UNAIDS 2005; Simbayi, Kalchman, Strebel, Cloete et al. 2007).

Such (mis)understandings have meant that HIV infection in South Africa has been labelled as the 'disease of others' (Hood 2013, 284), tied up as it is with the historical social hierarchy imposed by Apartheid (Skinner and Mfecane 2004). HIV in South Africa is discursively situated through the existing multiple layers of stigma towards Black people, women, homosexual people and the poor (Francis 2008). Such constructed differences along political, cultural and sociological lines highlight the intersections of power, inequality and social patterning of the disease (Lichtenstein and DeCoster 2014). If education is seen a vaccine to fight the HIV pandemic (Pattman 2006), and if educators are positioned as ambassadors of positive change in the lives of their learners (Wood 2009), then such interpretations of social patterns need challenging within teacher education programmes. The on-going complexities of HIV stigma and discrimination underscore the need to explore alternative and creative ways to disrupt such unqualified views and beliefs of PLWHA held by pre-service teachers. Thus, in my teaching I aim to help the students to 'read the world and understand' (Freire and Macedo 1987, 35) the forces of reproduction and the forces of transformation (Spaaij and Jeanes 2013, 444) with regard to HIV and AIDS education.

De Lange and Stuart (2013) recommend that teaching should be explored through interactive participatory approaches that produce knowledge to enhance human agency. One 
such an approach is to use critical lenses to understand the complexities associated with HIV. Critical pedagogy (Freire 2000) focuses on the interrogation of how well education meets the needs of the wider community. Critical pedagogy raises issues about inequalities of power, about false myths of opportunity and merit, and about the way belief systems become internalized to the point where individuals and groups abandon the very aspiration to question or change their lot in life (Burbules and Berk 1999). Freire's pedagogy of oppression (Freire 2001) challenges the notion of educators as sole experts and learners as empty vessels and positions them as active agents with responsibility to reduce bias and discrimination in order to foster safe school environments for all learners (Meyer 2010). Pre-service teachers need to learn to question the socioeconomic and cultural constructions of HIV and how they influence the vulnerability of people living with HIV. Reflexivity involves problem-posing rather than the mere answering of questions (Burbules and Berk 1999) and encourages dialogue to engender critical epistemological and ontological understandings of specific social constructions. As South Africa battles to heal from its historical wounds of oppression and discrimination, teachers today will have to identify and challenge the multiple forms of discrimination present in the education system (Kumshiro 2015) through being presented with opportunities to question and reformulate what is to be accepted as knowledge through structured learning activities.

\section{PROCESS AND METHODOLOGY}

This study was based on strategies to shift epistemologies around race, class and HIV with first year Life Orientation Teacher Education students at one university in South Africa. There were 86 students in this class comprised of predominantly White students specialising in Life Orientation in the Initial Teacher Training programme. Sixty-three of them were of White Afrikaner descent, 15 of Coloured descent and eight of African descent. These demographics are a near mirror to the student population of the whole campus which was (is) historically a White Afrikaner campus. Nduna and Mendes (2010) found evidence that remnants of apartheid thinking still influence the attitudes and behaviour of such cohorts.

At the beginning of the module, I asked students to discuss how HIV and AIDS were understood and talked about in their communities. Francis (2008) proposes addressing issues of oppression and inequality that would enable a departure from the student's personal content to an interrogation of institutional practices. Some of the responses included:

- $\quad$ HIV is not talked about 
- It is a black disease, as shown by statistics

- $\quad$ People with HIV are promiscuous

- $\quad$ HIV is spread by women sleeping with multiple partners

- $\quad$ HIV is caused by witchcraft.

To counteract such thinking, I organised a guest presentation by a White HIV positive speaker. Students were required to write a reflection on their previous understandings of HIV and AIDS compared to how they thought after listening to the presentation. As part of the reflection on the lecture, students had to draw an image of what their perceptions were before and after the guest lecture. Yuen (2004) found drawings to be a useful tool to investigate personal perceptions and experiences. Drawings as a research tool have the potential to elucidate emotions more powerfully than the spoken word (Knowles, Parnel, Stratton and Ridges 2013). All students had to draw a picture of their choice on their perceptions about HIV and AIDS before and after a guest lecture by a White person living with HIV. Public speaking by PLWHA has been found to reduce ignorance, dilute stigma and reduce prejudice between minority and majority group members (Brener, Wilson, Rose, Mackenzie et al. 2013). These pictures were used to facilitate reflective discussions during the class sessions. A total of 84 drawings with short captions and brief narratives were collected.

I used visual and content analysis to explore the meanings from the drawings and capture perceptions and new experiences of students (Creswell 2009). The data was triangulated by the use of an independent re-coder (Creswell 2009) with whom I had a consensus discussion before deciding on final themes. Students signed a consent form that allowed their visual artefacts and textual data to be used for research purposes and which assured their anonymity. This article discusses the students' critical reflections through their drawings and accompanying narratives.

\section{DISCUSSION OF FINDINGS}

The findings of this study are discussed under the themes which are indicative of the distinctive shifts in how students think about PLWHA. The first theme deals with HIV as a lived human experience rather than being a mere statistic. The second theme discusses the shift from viewing HIV as a disease of the 'other' to recognition of personal responsibility for how we treat people. The third theme highlights a shift from ignorance and bias to more nuanced understandings of HIV, and the last theme from seeing HIV as a symbol of death to one of hope and support. Some captions were written in Afrikaans, the language of instruction, and this is translated to aid comprehension. 
Theme 1: From viewing HIV as a 'thing' to recognizing the human face of HIV and AIDS

An outstanding characteristic of the majority of the drawings done after the lecture is an element of humaneness (see Figure 1).

\begin{tabular}{|l|l|l|}
\hline & Picture 2 \\
\hline
\end{tabular}

Figure 1: Examples of theme 1

During class discussions before the lecture, many students indicated that they know HIV through the red ribbon, the alarming infection statistics and the horrifying images of ill people often used as an educational tool. These were mainly marred images of Black Africans with severe levels of infected flesh and genitalia with skin lesions and rashes (Hood 2013). The 
experience of seeing a healthy-looking person with HIV contradicted this image. For the first time, they were confronted with a woman of similar socio-cultural background to themselves, who looked attractive and healthy. The captions accompanying the images of the heart highlight the idea that students are now aware of the painful human experiences that are associated with stigma and discrimination. The drawings depict new understandings of HIV and AIDS and the emergence of values of care and support for learners infected and affected by HIV in their future classrooms. Sarma, Islam and Gazi (2013), in their study with Bangladeshi teachers, discovered that they are more likely to implement HIV education successfully when they have a comprehensive understanding of how HIV affects the learners and are confident in ways to support and care for such learners. The shift from thinking about PLWHA as people with a dreadful disease to be avoided to seeing it as a condition that could be altered through compassion and care is critical in the role of effective and impactful HIV education to increase empathy and reduce stigmatization.

\section{Theme 2: From 'othering' to a concern for all}

HIV and AIDS perceptions before the guest lecture were still stratified along racial, social and self-righteous moral beliefs. As students did not necessarily see themselves within these groupings, they perceived HIV as a disease of the other due to the racialised perceptions of HIV (Mankayi 2009). The foregoing literature highlighted the existing racial divide inherited from the Apartheid history of South Africa. The portrayal of HIV as a result of extreme poverty (Hood 2013) intersects HIV with the Black person in South Africa who largely lives with the historical economic disadvantage. This distancing and falsified immunity of particularly White students from HIV has shaped their understanding and subsequent practices relating to HIV as can be seen in the drawings and narratives below.

Because of the historical divide between race in South Africa and the still existing racial stigma, HIV is a disease of 'those', the 'other', the poor and the Black man (Skinner and Mfecane 2004). Deacon (2014) explains that when people distance themselves and the selfdefined groups from the risk of infection they classify the other group as deviant. Such responses are concerning since all participants claimed that they learned about HIV at 


\begin{tabular}{|c|c|}
\hline $\begin{array}{l}\text { Bunca nflkay. } \\
\text { Fenale, } 20 \\
\text { White }\end{array}$ & 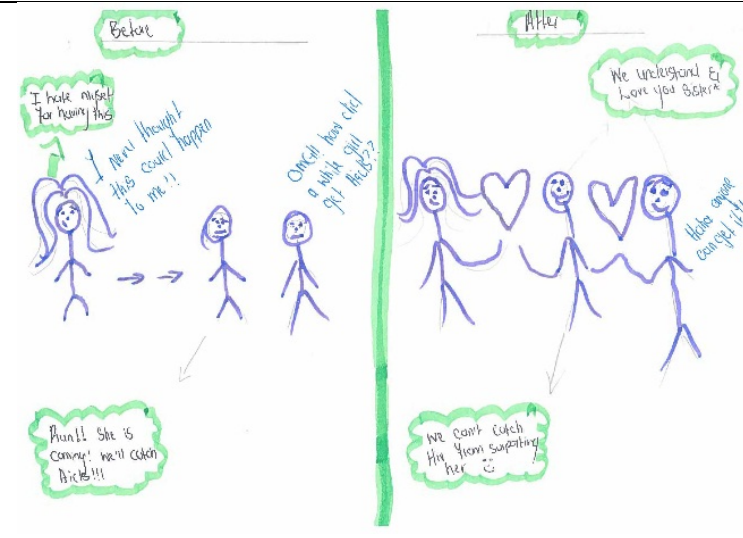 \\
\hline $\begin{array}{l}\text { Before } \\
\text { Only poor people get infected } \\
\text { A person living with AIDS is visibly identifiable } \\
\text { You only get infected by sleeping with many } \\
\text { partners } \\
\text { You die if are HIV positive }\end{array}$ & $\begin{array}{l}\text { Before } \\
\text { OMG how did a White girl get AIDS } \\
\text { I hate myself for having this } \\
\text { I never thought this could happen to me } \\
\text { Run she is coming, we will get AIDS }\end{array}$ \\
\hline $\begin{array}{l}\text { After } \\
\text { You make a difference in a life of a child } \\
\text { It is not a death sentence } \\
\text { It is not as infectious like flu symptoms } \\
\text { Live your dreams }\end{array}$ & $\begin{array}{l}\text { After } \\
\text { We understand, love you sister } \\
\text { Anyone can get it } \\
\text { We can't get HIV from supporting her }\end{array}$ \\
\hline $\begin{array}{l}\text { Do not quit } \\
\text { fight for you } \\
\text { life and you } \\
\text { will be brave. }\end{array}$ & $\begin{array}{l}\text { Picture } 3 \text { Before } \\
\text { I thought it was only poor people with multiple } \\
\text { sex partners that get infected } \\
\text { After } \\
\text { I now know that anyone can get infected } \\
\text { regardless your gender, race or age. } \\
\text { Belief and unite to fight this virus. } \\
\text { Face your problems they will melt away } \\
\text { Do not quit the fight for your life and you will be } \\
\text { brave. }\end{array}$ \\
\hline
\end{tabular}

Figure 2: Examples of Theme 2

secondary school. This raises the question of what students have learned about HIV and how the disease was portrayed and constructed. I was astounded to observe the change of views from students after only one guest lecture. The risk of not confronting the years of misinformation about HIV would be to send discriminatory teachers into the profession who would perpetuate prejudice and stigma. Such harmful personal values and beliefs are in conflict with optimal 
teaching and learning of the constitutional values of respect and nation building in South Africa (Helleve et al. 2011). It is thus critical to empower trainee teachers with tools to understand systemic discrimination and oppression and how to contest it. Confronting students with an HIV image of 'their own' transformed the misconceptions and harmful views of HIV as captured in the narratives below.

'We need to support those who are affected by HIV.'

'Haha, anyone can get it!!'

'All of us are infected by our own personal HIV infection.'

'Jy kan ' $n$ verskil maak in a kind se lewe al het hy/sy HIV.' (You can make a difference in the life of a child regardless of the HIV status.)

'Enige iemand kan dit kry.' (Anyone can be infected.)

The relocation of HIV in 'us', 'we' and 'all' is a departure point to reposition the disease as part of their professional identity and responsibility. Students had a very strong individualistic outlook towards the disease. Images drawn about views before the lecture portrayed little sense of care and support which should be a core characteristic of a Life Orientation teacher (Nel 2014). The individual outlook to the disease as portrayed in Figure 2 suggests that HIV is seen as the problem of the infected and should be treated as such. This outlook reflects the traditional medical model of disability and special education that focuses on elements of personal deficit (Muthukrishna 2008). The lack of compassion and support as seen in Figure 2 not only put HIV infected and affected learners at risk of falling through the safety net offered by the education system but rather all learners who are vulnerable.

The narratives below, about their pre-presentation attitudes, reveal that HIV was regarded as a medical condition that had no relation to education and that it was not something they were willing to discuss in teaching, apart from basic prevention information. Such perceptions would make learners more vulnerable to exclusion in the daily learning activities in the classrooms.

'Wat het dit met onderwys te doen?' (What does this have to do with education?)

'Was ongemaklik vir my' (It was uncomfortable for me.)

'Ek het gevoel om alleen te wees en was nie bekommerd of geen belangstelling gehad in andere nie. Ek was ook nie bekommerd oor die persone se statusse of probleme nie.' (I felt to be alone and was not bothered by others or had no interest in others. I had no concern about the status of neither others nor their problems.)

'Not my problem.'

'Knew about it but didn’t really pay attention.' 
A recurrent theme in all images post-presentation is that of care, support, understanding and a sense of community. Students pointed out in Figure 2 that HIV is every person's responsibility. Images show individuals (male and female) united, happy faces and holding hands.

'Ons moet mekaar se hande vat. Nie mense judge volgens hul status nie. Mekaar te kan vertrou en ondersteuning gee.' (We should take hands. Let us not judge others on the basis of their status.)

'We should trust one another and provide support.'

'Glo en staan saam en veg die virus.' (Belief and unite in fighting the virus.)

'Love and support can go a long way and stop judging before you know the facts.

'We need to support those who (infected and) affected by HIV.'

The HIV positive speaker did not just convey mere prevention or anti-stigmatization messages but the lived experiences of an individual. Pre-service teachers gained a realistic understanding of what they could be confronted with on a daily basis in the classroom. Images drawn in the lesson after the guest lecture depict human beings who hold hands, with hearts drawn between the human images and a tree that symbolizes life. These are messages of transformation and hope, positivity, care and support.

\section{Theme 3: From a lack of knowledge to new understandings about HIV}

The misconceptions students hold about HIV are an indication that there is a critical lack of knowledge about the human side of HIV and AIDS that reflects aspects of social justice, democracy and diversity. Moreover, it alludes to the quality of teaching about HIV and AIDS as well as of diversity education at school level. In addition, the lack of understanding about HIV directly perpetuates students' stigmatised views towards PLWHA (Matthews, Boon, Flisher and Schaalma 2006).

The drawings and narrative indicate the realization of students with regard to their limited knowledge about people living with HIV before the guest lecture. 


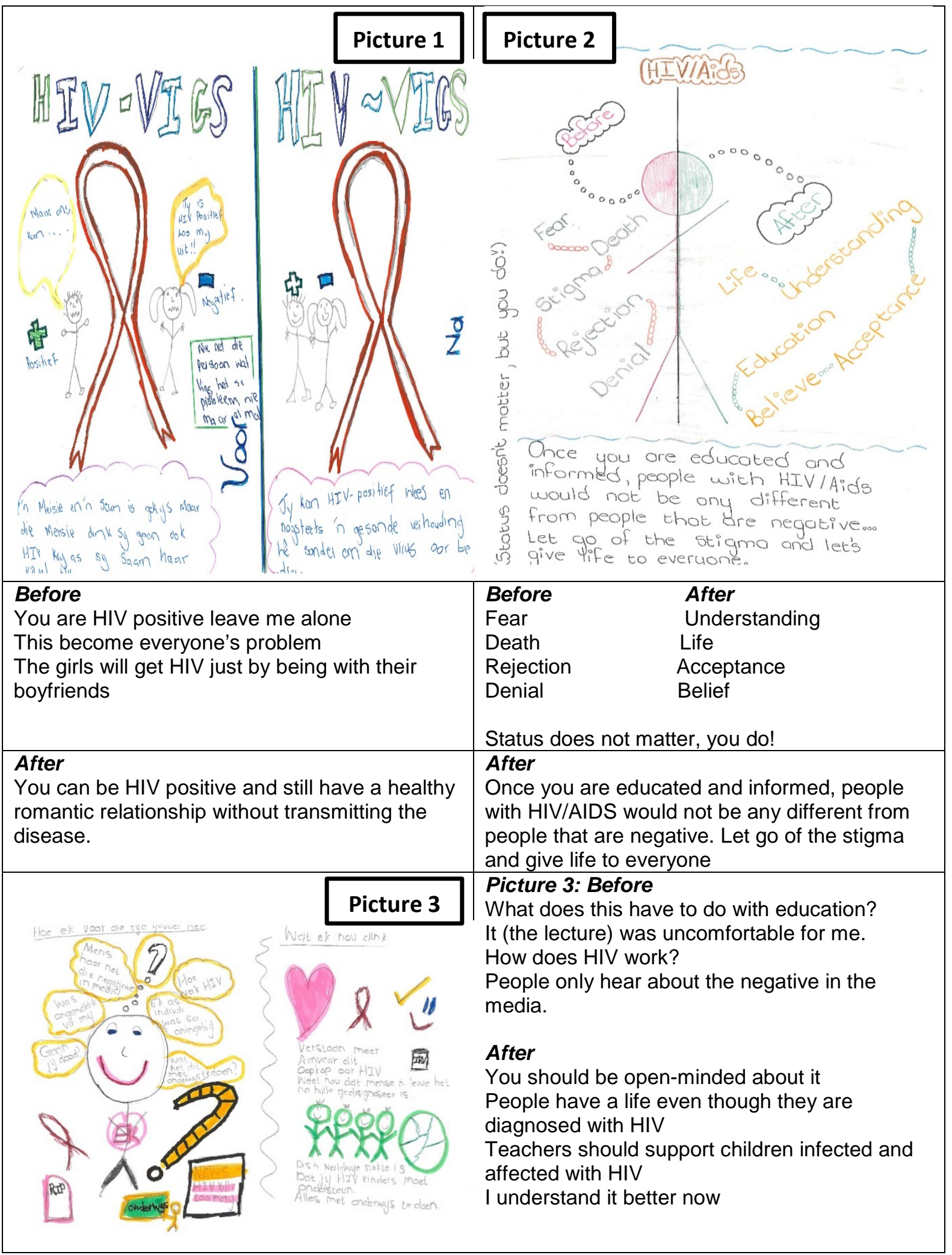

Figure 3: Examples of Theme 3

The lack of knowledge and understanding about HIV and AIDS does not only suggest stigma and discrimination towards PLWHA, but also the inability of students to assess their own risk of HIV infection. In addition, students' portrayal of HIV as a disease of others also points to 
their fear and discomfort for anything that represents 'other'. This could influence the willingness of these trainee teachers to address issues of HIV, race, gender, sexuality and class in the classroom (Sarma, Islam and Gazi 2013). The guest presentation was an extremely powerful tool to change stigmatized views of HIV and PLWHA and enabled students to voice more compassionate views:

'You can’t catch HIV from supporting her.'

'Always use a condom, it is free.'

'Dis nie aansteeklik soos 'n verkoue nie.' (It is not contagious like flu.)

Viewing HIV through a more humanizing lens has the power to bridge the divide between race, class and historical differences in South Africa. The newly constructed understandings of HIV encouraged students to consider introducing HIV education into their teaching from more than just a bio-medical perspective. In so doing, these future teachers will be able to better confront the attitudes that were constructed during the early days of the disease and promote values of care and support.

\section{Theme 4: From death and fear to hope and support}

Another strong perception recorded in the drawings relates to associations with death prior to the presentation. Regardless of the advances in medical knowledge and intervention practices that enable HIV positive people to live with a chronic disease, students still associated HIV with a sudden death sentence and perceptions of hopelessness, isolation and rejection. Prepresentation perceptions symbolised death through the visuals of coffins, tombstones, dead tree branches and church buildings with a cross. A second common feature is that of trees, which were depicted as dead and barren before but green and alive after the guest lecture (see Figure 4 , picture 2).

This myth of HIV as synonymous with death was disrupted by the speaker who informed them that she has been living with the disease for 16 years. This undeniable evidence that PLWHA could live a long life with the necessary care and support has changed students' views and supplanted this with compassion and empathy for people living with HIV. This shift from hopelessness to a positive outlook is a necessary one to inculcate in learners, especially those who face multiple adversities in life. Larson (2013) argues that hope is more than survival, that survival is not necessarily an indicator of thriving, and that to thrive, youth need to find hope. Hope is positively related to effective goal setting and a feeling of agency 


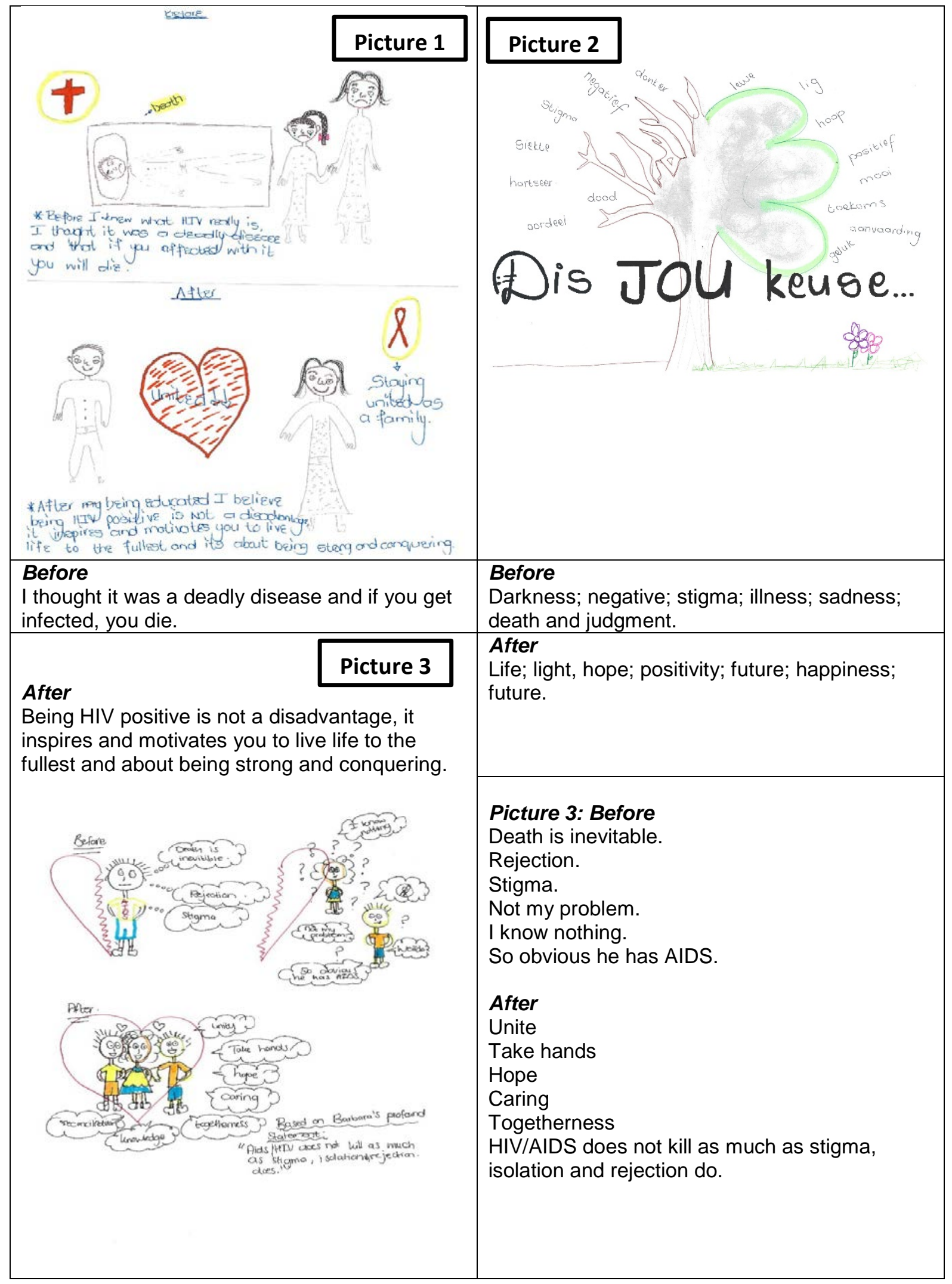

Figure 4: Examples of Theme 4

(Snyder 2002), and the job of the teacher (of any subject) is to help learner to develop such 
skills, in addition to increasing content knowledge. By busting the myth of HIV as a death sentence or a life of chronic illness, the presentation helped to shift the thinking of these preservice teachers about PLWHA as having a purposeless life to being able to see the value that they can add irrespective of their sero-status. If teachers cannot operate from a position of hope, then there is little chance that they will be able to help learners in this regard.

\section{CONCLUSION}

This study shows that the discourse of HIV along race, class and gender continues to characterise perceptions of the HIV-AIDS condition among certain student populations, regardless of the numerous research and education campaigns in the fight of stigma. The health consequences of HIV transmission myths and representational trends need to be taken seriously in the attempts of anti-HIV stigma education (Hood 2013). The South African historical consequences of discrimination and 'othering' have to be treated as opportunities to develop agency among student teachers. To prepare an informed teacher corps on citizenry, teacher education institutions should expose students to critical understandings of the structures that perpetuate oppression, domination and exclusion in society (Muthikrishna 2008). The use of the HIV positive speaker and the critical pedagogical strategy of drawing became a critical lens through which valuable lessons could be learned. The transformed thinking from a false sense of security and imagined immunity to a position of care, compassion and understanding was a recurrent feature of the narratives. It is too early to guarantee the articulation of the depathologised views of HIV into teaching practice but this learning provides a foundation that pre-service teachers could use to further nurture values of inclusivity and humanity essential for care and support in the education system. The participants in this study have three years more to complete this course and this learning will hopefully fertilize the mental ground for the cultivation of the development of new insights into the complexities of diversity that they will be faced with, both in the classroom and in their personal lives. Rather than just teaching about 'responsible citizenship' they may be able to actually live out the values of compassion and care that will help to address the prevailing stigma associated with HIV and its intersectionality with other issues of social (in)justice.

\section{REFERENCES}

Borrero, N. E., J. C. Yeh, C. I. Cruz and J. F. Suda. 2012. School as a context for 'othering' youth and promoting cultural assets. Teachers College Record 114(2): 1- 37.

Brener, L., H. Wilson, G. Rose, A. Mackenzie and J. de Wit. 2013. Challenging stereotypes and changing attitudes: Improving quality care for people with hepatitis $\mathrm{C}$ through positive speakers programs. Psychology, Health \& Medicine 18(2): 242- 249. 
Brown, D. C., R. BeLueb and C. O. Airhihenbuwa. 2010. HIV and AIDS related stigma in the context of family support and race in South Africa. Ethnicity and Health 15(5): 441-458.

Burbules, N. C. and R. Berk. 1999. Critical thinking and critical pedagogy: Relations, differences, and limits. In Critical theories in education: Changing terrains of knowledge and politics, ed. T. S. Popkewitz and L. Fendler, 45-65. New York: Routledge.

Creswell, J. 2009. Research design: Qualitative, quantitative, and mixed methods approach. SAGE Publications, Incorporated.

Deacon, H. 2006. Towards a sustainable theory of health-related stigma: lessons from the HIV/AIDS literature. Journal of Community \& Applied Social Psychology 16(6): 418-425.

De Lange, N. and J. Stuart. 2013. Innovative teaching strategies for HIV and AIDS prevention and education. In Dealing with HIV and AIDS in the classroom, ed. L. Wood, 3-26. Cape Town: JUTA.

Department of Basic Education. 2012. Integrated Strategic Plan on HIV and AIDS. Pretoria: Department of Basic Education.

Francis, D. 2008. Beyond HIV, there is stigma, there is activism. In Educating for social justice and inclusion in an African context, ed, N. Muthukrisna, 207-221. New York: Nova Science Publishers, Inc.

Freire, P. 2001. Pedagogy of freedom: Ethic, democracy, and civic courage. Lanham, MD: Rowman \& Littlefield.

Freire, P. and D. Macedo. 1987. Literacy: Reading the word and the world. South Hadley, MA: Bergin and Garvey.

Hamra, M., M. W. Ross, K. Karuri, M. Orr and A. D’Agostino. 2005. The relationship between expressed HIV/AIDS-related stigma and beliefs and knowledge about care and support with people living with AIDS in families caring for HIV-infected children in Kenya. AIDS Care 17(17): 911-922.

HEAIDS. 2010. Curriculum-in-the-making - Being a teacher in the context of the HIV and AIDS pandemic: Teacher Education Pilot Project. Pretoria: Higher Education South Africa.

Helleve, A., A. J. Flisher, H. Onya, S. Kaaya, W. Mukoma and K. Klepp. 2009. Teachers' confidence in teaching HIV/AIDS and sexuality in South African and Tanzanian schools. Scandinavian Journal of Public Health 37(Suppl 2): 55-64.

Helleve, A., A. J. Flisher, H. Onya, W. Mukoma and K. Klepp. 2011. Can any teacher teach sexuality and HIV/AIDS? Perspectives of South African Life Orientation teachers. Sex Education: Sexuality, Society and Learning 11(1): 13-26.

Holderness, W. L. 2012. Equipping educators to address HIV and AIDS: A review of selected teacher education initiatives. SAHARA 9(S1): S48-S55.

Hood, J. 2013. Distancing disease in the un-black Han Chinese politic: Othering difference in China's HIV/AIDS media. Modern China 39(3): 280-318.

Knowles, Z. R., D. Parnell, G. Stratton and N. D. Ridges. 2013. Learning from the experts: Exploring playground and activities using a write and draw technique. Journal of Physical Activity and Health 10: 406-415.

Krumer-Nevo, M. and M. Sidi. 2012. Writing against othering. Qualitative Inquiry 18(4): 299-309.

Kumshiro, K. K. 2015. Against common sense: Teach and learning social justice. Routledge: London.

Larson, S. 2013. The power of hope. Reclaiming Children and Youth 21(4): 44-46.

Lichtenstein, B. and J. DeCoster. 2014. Lessons on stigma teaching about HIV/AIDS. Teaching Sociology 42(2): 140-150.

Mankayi, N. 2009. Military men and sexual practices: Discourse of 'othering' in safer sex in the light of HIV/AIDS. Journal of Social Aspects of HIV 6(1): 33-41.

Mathews, C., H. Boon, A. J. Flisher and H. P. Schaalma. 2006. Factors associated with teachers' 
implementation of HIV/AIDS education in secondary schools in Cape Town, South Africa. AIDS care 18(4): 388-397.

Meyer, E. J. 2010. Gender and sexual diversity in schools. Springer: London.

Mitchell, C., N. Delange, R. Moletsane, J. Stuart and T. Buthelezi. 2005. Giving a face to HIV and AIDS: On the uses of photo-voices by teachers and community health care workers working with youth in rural South Africa. Qualitative Research in Psychology 2: 257-270.

Muthukrishna, N., ed. 2008. Educating for social justice and inclusion in an African context. New York: Nova Science Publishers.

Nduna, M. and J. Mendes. 2010. Negative stereotypes examined through the HIV and AIDS discourse: Qualitative findings from white young people in Johannesburg, South Africa. Journal of Social Aspects of HIV/AIDS 7(3): 21-28.

Nel, M. 2014. Pedagogy of Life Orientation, Life Skills. In Life Orientation for South African Teachers, ed. M. Nel. Pretoria: Van Schaik.

Parker, R., P. Aggleton, K. Attawell, J. Pulerwitz and L. Brown. 2002. HIV/AIDS related stigma and discrimination: A conceptual framework and agenda for action. HIV/AIDS Policy and Law Review 7(2/3): 115-116.

Pattman, R. 2006. Making pupils the resources and promoting gender equality in HIV/AIDS education. Journal of Education 38: 89-115.

Promtusananon, S. and K. Peltzer. 2005. Perceptions of tuberculosis: Attributes of cause suggested means of risk reduction and preferred treatment in Limpopo province, South Africa. Journal of Health Population Nutrition 23(1): 74-81.

Rao, D., T. C. Kekwaletswe, S. Hosek, J. Martinez and F. Rodriquez. 2007. Stigma and social barriers to medication adherence with urban youth living with HIV. AIDS Care 19(1): 28-33.

Sarma, H., M. A. Islam and R. Gazi. 2013. Impact of training teachers on their ability, skills, and confidence to teach HIV/AIDS in classroom: A qualitative assessment. BMC Public Health 13: 990-1007.

Simbayi, L. C., S. Kalichman, A. Strebel, A. Cloete, N. Henda and A. Mqeketo. 2007. Internalized stigma, discrimination, and depression among men and women living with HIV/AIDS in Cape Town, South Africa. Social Science and Medicine 64: 1823-1831.

Skinner, D. and S. Mfecane. 2004. Stigma, discrimination and the implications for people living with HIV/AIDS in South Africa. Journal Aspects of HIV/AIDS 1(3): 157-164.

Snyder, C. R. 2002. Hope Theory: Rainbows in the mind: An psychological inquiry. International Journal for the Advancement of Psychological Theory 13(4): 249-275.

Spaaij, R. and R. Jeanes. 2013. Education for social change? A Freirean critique of sport for development and peace. Physical Education and Sport Pedagogy 18(4): 442-457.

Statistics South Africa. 2014. Mid-Year population estimates. Pretoria: Statistics South Africa.

Swartz, S., E. Arogundade and D. Davis. 2014. Unpacking (white) privilege in a South African university classroom: A neglected element in multicultural educational contexts. Journal of Moral Education 43(3): 345-361.

Themane, M. J. and M. J. Taole. 2013. Student-teachers' HIV/AIDS knowledge and their risky sexual behaviour at a South African rural-based university. African Journal for Physical, Health Education, Recreation \& Dance 19(3): 75-85.

UNAIDS. 2005. Monitoring the declaration of commitment on HIV/AIDS: Guidelines on construction of core indicators. Paris: World Health Organization.

Van Breda, A. D. 2012. Stigma as ‘othering' among Christian theology students in South Africa. Journal of Social Aspects of HIV 9(4): 181-191.

Van Dyk, A. 2012. HIV and AIDS. Education, care and counselling: A multidisciplinary approach. Pearson: Cape Town. 
Vinkenburg, C. J. 2014. Us, them, and others in management research. Academy of Management Research 39(3): 382-386.

Watkins-Hayes, C. 2014. Intersectionality and the sociology of HIV/AIDS: Past, present, and future research directions. Sociology 40: 431-457.

Wood, L. 2009. What kind of respect is this? Shifting the mindset of teachers regarding cultural perspectives on HIV and AIDS. Action Research 7: 405-422.

Wood, L., ed. 2013. Dealing with HIV and AIDS in the classroom. Cape Town: JUTA.

Wood, L. and L. Rolleri. 2014. Designing an effective sexuality education curriculum for schools: Lessons gleaned from the South(ern) African literature. Sex Education 14(5): 525-542.

Yuen, F. C. 2004. 'It was fun ... I liked drawing my thoughts': Using drawing as part of a focus group process with children. Journal of Leisure Research 36(4): 461-482. 